\title{
AGRIBUSINESS BEHAVIOR OF MANGO FARMERS IN THE DISTRICT OF PANYINGKIRAN MAJALENGKA REGENCYBASED ON MANGO OWNERSHIP
}

\author{
Elly Rasmikayati, ${ }^{1}$ Bobby Rachmat Saefudin, ${ }^{2}$ Hendrik J. Nadapdap, ${ }^{3}$ and Fitri Awaliyah ${ }^{4}$ \\ ${ }^{1}$ Faculty of Agriculture, Padjadjaran University, Jl. Bandung-Sumedang KM. 21, Jatinangor, 45363 \\ ${ }^{2}$ Faculty of Agriculture, Ma'soem University, Jl. Raya Cipacing No.22, Jatinangor, 45363 \\ ${ }^{3}$ Faculty of Agriculture, Universitas Kristen SatyaWacana, Jl.Diponegoro No.52-60, KotaSalatiga, 50711 \\ ${ }^{4}$ Faculty of Agriculture, Garut University, Jl. Raya Samarang No.52, KabupatenGarut, 44151 \\ E-mail: e.rasmikayati@unpad.ac.id; bobbyrachmat@masoemuniversity.ac.id; hendrik.nadapdap@uksw.edu; \\ fitriawaliyah@uniga.ac.id
}

\begin{abstract}
Mango varieties of Arumanis and GedongGincu is one of the horticultural commodities that are superior to Indonesian exports. The high local and international demand also makes the consumers preference of mango higher. Nevertheless, the development of mango agribusiness related to behavior of agribusiness farmers and the amount of mango trees is still not optimal. This study aims to determine the relationship between the agribusiness behavior of mango farmers and the number of mango trees. The method used in this study is a survey method with descriptive statistical and Chi-Square analysis tools. The results showed that the majority of mango farmers in Panyingkiran sub-district, Majalengka regency are farmers with narrow land (0.1-1 Ha) with the status of privately land. Farmers with privately status is command $<50$ mango trees on their land, while farmers who control $>200$ mango trees are farmers with rental tree status. Farmers with little, medium, and large amounts of mango trees use private capital to cultivate mangoes and easily gain access to farm credit. The farmer makes the middleman as the final market destination and uses a cash payment system in buying and selling transactions. There are 6 variables of agribusiness behavior of mango farmers in Panyingkiran District, Majalengka Regency, which have a good and significant relationship with mastery of the number of mango trees, namely access to farm credit, application of off season technology, percent of good quality yields (grade A/B), determinants selling prices, payment systems and membership in farmer groups.
\end{abstract}

Key words: agribusiness development; agribusiness behavior; mango farmer; farm credit; off season technology

\section{PERILAKU AGRIBISNIS PETANI MANGGA DI KECAMATAN PANYINGKIRAN KABUPATEN MAJALENGKA DITINJAU DARI PENGUASAAN MANGGA}

\begin{abstract}
ABSTRAK. Mangga dengan varietas Arumanis dan Gedong Gincu merupakan salah satu komoditas hortikultura yang menjadi unggulan ekspor Indonesia. Tingginya permintaan local dan internasional menjadikan semakin tinggi pula preferensi buah mangga sebagai pemenuhan kebutuhan vitamin, serat, mineral, dan kalori bagi konsumen. Meskipun demikian, pengembangan agribisnis mangga dari segi perilaku agribisnis petani dan jumlah penguasaan pohon belum optimal. Penelitian ini bertujuan untuk mengetahui keterkaitan antara perilaku agribisnis petani mangga dengan jumlah penguasaan pohon. Metode yang digunakan dalam penelitian ini adalah metode survey dengan alat analisis statistic deskriptif dan Chi-Square test. Hasil penelitian menujukkan bahwa mayoritas petani mangga di Kecamatan Panyingkiran, Kabupaten Majalengka merupakan petani berlahan sempit (0,1-1 Ha) dengan status penguasaan lahan milik pribadi. Petani dengan status pohon milik menguasai $<50$ pohon mangga di lahannya, sedangkan petani yang menguasai >200 pohon mangga merupakan petani dengan status pohon sewa. Petani dengan penguasaan pohon mangga sedikit, sedang, dan banyak menggunakan modal pribadi untuk mengusahakan mangga dan mudah memperoleh akses untuk kredit usahatani. Petani tersebut menjadikan tengkulak sebagai tujuan pasar akhir dan menggunakan system pembayaran tunai dalam transaksi jual-beli. Terdapat 6 variabel perilaku agribisnis petani mangga di Kecamatan Panyingkiran, Kabupaten Majalengka yang memiliki keterkaitan yang erat dan signifikan dengan penguasaan jumlah pohon mangganya yaitu variable akses terhadap kredit usahatani, penerapan teknologi off season, persen hasil panen kualitas baik (grade A/B), penentu harga jual, system pembayaran dan keanggotaan dalam kelompok tani.
\end{abstract}

Kata kunci: pengembangan agribisnis; perilaku agribisnis; petani mangga; kredit pertanian; teknologi off season

\section{INTRODUCTION}

Indonesia is a tropical country that has abundant biodiversity and fertile natural conditions for agriculture. As a tropical country, Indonesia has a good opportunity to position itself as one of the world's agricultural commodity producers. The tropical climate makes Indonesia one of the places for the availability of various types of agricultural commodities. One of Indonesia's leading agricultural commodities is mango.

Mango fruit with varieties Arumanis and Gedong Gincu is one of the horticultural commodities that are superior to Indonesian exports. The high local and international demand also makes the preference of mango higher as meeting the needs of vitamins, fiber, minerals, and calories for consumers. Indonesia is a tropical country and has the potential to develop various kinds of agricultural commodities including mango. Mango plants can grow in almost all regions in Indonesia with rainfall of $750-2,000 \mathrm{~mm}$ / year and altitude of less than 300 meters above sea level.

In Indonesia, there are several provinces which are the centers of national mango production, West Java Province. Mango production data from West Java is shown in Table 1. 
Namely: the Provinces of East Java, Central Java, and West Java which are the major mango producers in Indonesia. Mango-producing areas in West Java are spread over 27 regencies and cities. There are 5 regencies in West Java as mango production centers namely Indramayu, Cirebon, Majalengka, Kuningan, and Sumedang.

Table 1. Mango Production in the Central Region of Mango in West Java

\begin{tabular}{cccccc}
\hline \multirow{2}{*}{ Regency } & \multicolumn{5}{c}{ Year } \\
\cline { 2 - 6 } & 2011 & 2012 & 2013 & 2014 & 2015 \\
\hline Kuningan & 44.868 & 39.377 & 32.406 & 23.329 & 32.108 \\
Cirebon & 55.981 & 62.053 & 30.945 & 51.661 & 37.443 \\
Majalengka & 43.280 & 48.521 & 10.243 & 57.172 & 64.394 \\
Sumedang & 21.169 & 29.008 & 23.607 & 20.633 & 23.491 \\
Indramayu & 63.057 & 68.506 & 84.788 & 72.436 & 69.737 \\
\hline
\end{tabular}

(Source: Directorate General of Horticulture, Ministry of Agriculture, 2015)

Based on Table 1, of the five regions of mango centers in West Java, one of which is Majalengka Regency in general has increased production from 2010 to 2015 only in 2013 this region has decreased. Based on the production data, it is known that the amount of mango production increases by an average of $26 \%$ annually. This shows the potential of Majalengka Regency as a mango producing center in West Java, because it can maintain a relatively stable production level and even increase. Majalengka Regency as one of the mango producing centers in West Java in 2014 had a mango plantation area of 10,880 ha with a harvest area of 7,502 ha indicating that of the total existing mango plantations, $68 \%$ of them produced productive mangoes (Kast and Rosenzweig, 1995; and Elfadina et al., 2019).

In fact, the number of trees or the number of mango plants is very influential on the results of mango production at harvest. Knowing the number of plant populations per unit area (for example per hectare) is especially important for mango cultivating farmers. By knowing the number of plants per unit area (hectares), farmers can plan fertilizers and labor more precisely, which in the end needs the costs needed to purchase fertilizer and labor costs can be calculated quickly and accurately.

Majalengka Regency is one of the mango producing centers in West Java, which in 2014 had a mango plantation area of 10,880 ha with a harvest area of 7,502 ha (Rachmah et al., 2019).Panyingkiran District has the largest area of harvest and the number of mango production in Majalengka Regency. In 2014, the total area of mango planting in this district was 1,854 hectares and the total area of mangoes was 1,733 Ha.In other words, 93\% of mango plants in Panyingkiran District succeeded in producing well. Average mango production in Panyingkiran District is $110 \mathrm{Kw} / \mathrm{Ha}$ (Directorate General of Horticulture, Ministry of Agriculture, 2015).

The success of mango agribusiness cannot be separated from farmers as makers, and decision makers in carrying out farming activities.According to Irianto and Widiyanti (2013), problems that often arise in mango agribusiness in general are problems ranging from the production stage to the mango marketing stage and have not fully provided optimal incentives to farmers.In addition, many mango farmers who have sold to modern markets do not continue because they cannot meet the quality requirements set by the modern market (Sari et al., 2019).

According to Kartasasmita, 1996; Suprapto 1997; Saragih 1998a; Solahuddin, 1998; and Saefuddin, 1998 in Suparta (2005), the welfare of farmers can be achieved if farmers can apply industrial culture agribusiness behavior, namely: (1) persevering, resilient, hard work, saving, careful, disciplined and respecting time; (2) able to plan and manage a business; (3) always upholding the principles of efficiency and productivity, (4) using technology especially appropriate technology and environmentally friendly, (5) having a strong motivation to succeed, (6) oriented to product quality and market demand, (7) oriented towards added value, (8) able to control and utilize nature, (9) responsive to innovation, (10) dare to face business risks, (11) conduct integrated agribusiness and vertical integration, (12) enrichment must replace dependence on nature so that products the result always fulfills the requirements of the market, and (13) professional and independent in making decisions.

In developing mango agribusiness, it is necessary to consider all aspects that are interrelated. It is not only enough to look at the behavior of the farmers or the mango agribusiness subsystem partially, but also the relationship between the agribusiness behavior of farmers and the ownership of the number of mango trees in the land under their control and how the potential of mango farming has been carried out by farmers, especially in the District of Panyingkiran, Majalengka regency.

\section{METHOD}

\section{Research design}

The research design used is quantitative, in which the researcher's steps have been designed so that they are structured and systematic. Meanwhile, the method used is a survey method with a questionnaire instrument.

\section{Sample Determination Techniques}

The sampling technique in this study is the Simple Random Sampling technique. By using the Slovin formula Description:

$$
\begin{aligned}
& \mathrm{n}=\frac{N}{1+N\left(d^{2}\right)} \\
& \mathrm{n} \quad=\text { Number of Samples } \\
& \mathrm{N} \quad=\text { Total population } \\
& \mathrm{d}^{2} \quad=\text { Precision established }
\end{aligned}
$$


The population in this study were 919 mango farmers in Panyingkiran Sub-District, Majalengka Regency, which incorporated in the farmers groups (Basedon calculation from the chairman of Gapoktan).With the level of precision is $8.1 \%$, based on the formula sample (n) is obtained as follows:

$$
\begin{aligned}
& \mathrm{n}=\frac{919}{1+919(0,081)^{2}}=130 \\
& \mathrm{n}=130
\end{aligned}
$$

So that it can be determined the number of samples is 130 mango farmers in the District of Panyingkiran.

\section{Variables and Data Analysis}

Data analysis tools used to answer research problems are descriptive statistical analysis and chi-square analysis. Descriptive statistical analysis is a technique for analyzing the behavioral data characteristic of mango farmers (age, level of education, income from mango farming, mango farming experience and mango productivity) so that it is easy to understand. Descriptive statistical techniques used are table and Pie charts.

While chi-square analysis is a statistical analysis method used to see the relationship of the combination of two or more variables which in this case is the ownership variable of the number of mango trees (land area and number of mango trees) with the agribusiness behavior of mango farmers (sources of capital, access to farm credit, number of family workers, application of off season technology, pest control, good quality crop yields (grade A / B), market selection, price determination, payment system, membership in farmer groups and government contributions related to mango farming (Rasmikayati et al., 2019).The hypothesis used is:

$\mathrm{H}_{0}$ : There is no relationship between land tenure area and $\mathrm{x}$ variable

$\mathrm{H}_{1}$ : There is a relationship between land tenure area with $\mathrm{x}$ variable

The null hypothesis can be tested using the Chisquare formula:

$\chi^{2}=\sum_{i=1}^{k} \frac{\left(0_{i}-E_{i}\right)^{2}}{E_{i}}$

Description :

$\chi^{2}=$ factors related to the extent of land ownership of mango farmers

$\mathrm{O}_{i}=$ the number of reality frequencies on the $\mathrm{x}$ variable

$E_{i}=$ number of expected frequencies on a $\mathrm{x}$ variable

$k=$ number of rows in crosstab

$d f=k-1$ (degree of freedom)

Based on this hypothesis, with value $\alpha=0,05$ Decision criteria obtained namely:

- $\mathrm{H}_{0}$ rejected if Asymp Sig $<0.05$, or

- $\mathrm{H}_{0}$ accepted if the Asymp Sig>0.05.

\section{RESULTS AND DISCUSSION}

\section{Characteristics of Mango Farmers}

The success of mango farming is determined by the characteristics of farmers as farming actors, makers and decision makers in carrying out farming activities. Farmer characteristics are personal data owned by farmers or characteristics inherent in individual farmers that can distinguish with other farmers. According to Hapsari et al. (2019), despite being in the same residential and cultural environment, the characteristics of each farmer are very diverse, known from the age group of the head of the family, the level of education of the head of the family, the main profession of the family and the extent of land ownership.

The characteristics of farmers observed in this study are age, gender, level of education and experience of mango farming.

\section{Age of Mango Farmers}

Age can be used as a benchmark in seeing someone's activity in doing a job. Someone can work better and maximum in conditions of productive age. The following is a data table on the age of mango farmers in the District of Panyingkiran.

\section{Table 2. Characteristics of Farmers by Age}

\begin{tabular}{cccc}
\hline No. & $\begin{array}{c}\text { Age } \\
(\text { years })\end{array}$ & Total (people) & $\begin{array}{c}\text { Percentage } \\
(\%)\end{array}$ \\
\hline 1. & $<30$ & 6 & 5 \\
2. & $31-40$ & 23 & 18 \\
3. & $41-60$ & 74 & 57 \\
4. & $>61$ & 27 & 21 \\
& Total & 130 & 100 \\
\hline
\end{tabular}

(Source: Primary Data, Processed, 2019)

Based on Table 2, it is known that the majority of mango farmers in the District of Panyingkiran namely $57 \%$ of the total respondent farmers who are farmers with age categories 41-60 years including productive age at work. Mango farmers with age below or equal to 30 years old at least even though that age is the age where someone has good working power. This can show that not many young people have the desire to become farmers, especially mango farming. As information from several respondents it is noted that their children prefer to work in offices and cities than in the agricultural sector, especially mango farming.

\section{Gender of Mango Farmers}

Based on Table 3, it is known that there are more male farmers than female farmers, this is because men are the family heads who are responsible for their families, whereas women are more dominant in taking care of domestic household affairs. The female mango farmer who is a widow inherited from her previous mango orchard, help her husband to mango farming, or is the leader of the mango farmer group. 
Table 3. Farmer Characteristics by Gender

\begin{tabular}{cccc}
\hline No. & Gender & Total (people) & $\begin{array}{c}\text { Percentage } \\
(\%)\end{array}$ \\
\hline 1. & Men & 119 & 92 \\
2. & Women & 11 & 8 \\
& Total & 130 & 100 \\
\hline
\end{tabular}

(Source: Primary Data, Processed, 2019)

\section{Mango Farmer Education Level}

The level of education is the number of years of attending formal education taken by farmers in school. The level of education will be able to influence and change the mindset and reasoning for the better so that the mindset will become more rational. The level of education of mango farmers in the District of Panyingkiran varies from elementary to university.

The majority of mango farmers in the District of Panyingkiran have the last elementary school education which is $55 \%$ of the total respondents. There are still farmers who do not go to school $4 \%$ of the total respondent farmers, and only $3 \%$ of farmers have taken education to the University.

Table 4. Characteristics of Farmers by Education Level

\begin{tabular}{clcc}
\hline No. & $\begin{array}{c}\text { Level of } \\
\text { education }\end{array}$ & Total (people) & $\begin{array}{c}\text { Percentage } \\
(\%)\end{array}$ \\
\hline 1. & No school & 5 & 4 \\
2. & E 1 e m e n t a r y & & \\
3chool & Junior school & 20 & 55 \\
4. & High school & 27 & 15 \\
5. & Diploma & 2 & 21 \\
6. & Bachelor & 4 & 2 \\
\hline & Total & 130 & 3 \\
\hline
\end{tabular}

(Source: Primary Data, Processed,2019)

the level of education of mango farmers in the District of Panyingkiran, the mango farmers belong to the category of farmers with low education levels so that it is difficult to digest information and adopt innovations regarding technology and better implementation of mango farming activities. The cause of the large number of respondents with an education level is limited to elementary school, influenced by the lack of attention to education and the limited costs of continuing education to a higher level.

\section{Mango Farming Experience}

Experience is knowledge experienced by someone in an unspecified period of time.A pleasant and satisfying experience will have a positive impact on continuing to adopt innovation. The experience of farmers in farming has an important role in achieving success in the current mango farming. In general, the longer the experience of farmers in farming, the better the ability to manage farming.

Agribusiness Behavior of Mango Farmers in The District of Panyingkiran Majalengka Regencybased on Mango Ownership (Elly Rasmikayati, Bobby Rachmat Saefudin, Hendrik J. Nadapdap, and Fitri Awaliyah)
Table 5 shows that of the 130 respondents as mango farmers in the District of Panyingkiran, 67 people or 51\% of the total respondents are farmers with less experience in mango farming, with 5-15 years experience and 45 people or $35 \%$ of the total respondents as a mango farmer with a fairly experienced farming experience of 16-30 years. But since around the year 2000 the cultivation and farming of mangoes has begun to be intensely promoted so as to make many farmers switch commodities to become mango commodity cultivation. This is also evidenced by the large number of paddy fields owned by mango farmer respondents who were converted into mango orchards. In addition, many of the farmers have inherited the form of land or mango trees so that they continue the mango farming to date.

Table 5. Characteristics of Farmers Based on Mango Farming Experience

\begin{tabular}{cccc}
\hline No. & $\begin{array}{c}\text { Farming Experience } \\
(\text { Year) }\end{array}$ & Total (people) & $\begin{array}{c}\text { Percentage } \\
(\%)\end{array}$ \\
\hline 1. & $5-15$ & 67 & 51 \\
2. & $16-30$ & 45 & 35 \\
3. & $31-50$ & 15 & 12 \\
4. & $>50$ & 3 & 2 \\
\hline & Total & 130 & 100 \\
\hline
\end{tabular}

(Source: Primary Data, Processed,2019)

Usually farmers who have only worked on mangoes for about 5 years do not own land of mango and private mango trees but they rent to other mango tree owners who have productive mango trees. Even if they turn out to have land or private mango trees, the numbers are very small and the mango trees they have are not productive. Whereas respondents of mango farmers who have been farming mango for more than 50 years are generally mango farmers who already own land or private mango trees and tend not to lease land or mango trees for other people. The average length of mango farming experience of respondent farmers is 18 years.

\section{Ownership of Total Mango Trees}

The majority of mango farmers in the District of Panyingkiran, Majalengka Regency are farmers with narrow land (0.1-1 Ha) with the status of ownership of privately owned land. Farmers with ownership tree status,control $<50$ mango trees on their land while farmers who control $>200$ mango trees are farmers with leased tree status (Figure 1).

Access to information on cultivation, marketing, and climatic conditions related to mango farming is declared easy by farmers. Maximum mango productivity ever produced by farmers is around $100-300 \mathrm{~kg} /$ tree / season (Figure 2). This amount is produced by mango trees that are at least 10 years or can also be called a medium or mature tree. Mango varieties can also determine the amount of productivity of a mango or tree. An example is the Cengkir variety which is quite large in size so that one Cengkir mango tree is the same age as other varieties (eg 
with Gedong mango) can produce mangoes with a total weight that is much larger.

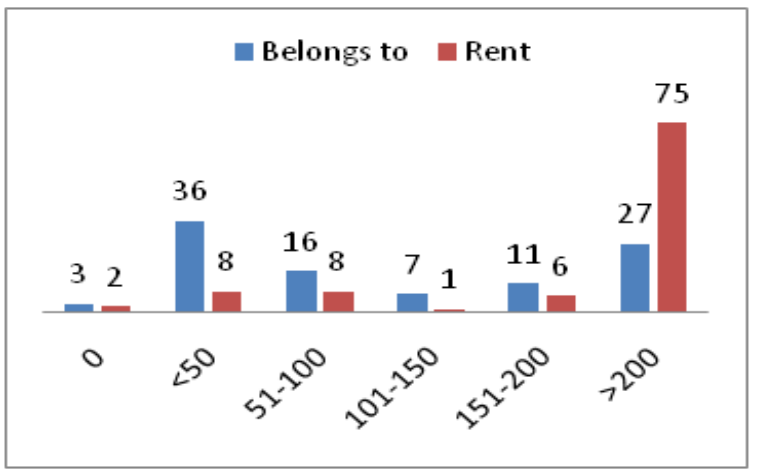

(Source: Primary Data, Processed, 2019)

Figure 1. Percentage of Mango Farmers Based on Ownership and Leasing Status

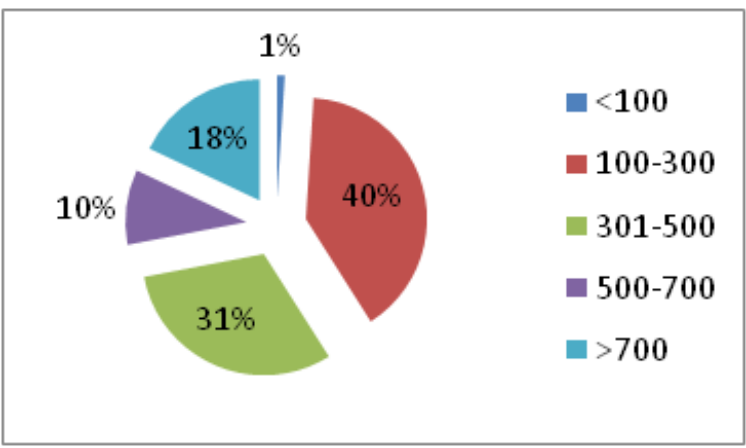

(Source: Primary Data, Processed, 2019)

Figure 2. Percentage of Mango Farmers Based on Mango Productivity (Kg / Season / Hectare))

Linkage of Mango Farmer Agribusiness Behavior with Ownership of Number of Mango Trees

The results of the Chi-Square test between the agribusiness behavior variables of mango farmers and the control of the number of mango trees are presented in Table 6. There are 6 variables of agribusiness behavior of mango farmers in the District of Panyingkiran, Majalengka Regency, which have a close and significant relationship with ownership of the number of mango trees, namely access to farming credit, off-season technology implementation, percent yield of good quality (grade $\mathrm{A} / \mathrm{B}$ ), determinants of selling prices, payment systems and membership in farmer groups.

The source of capital is one of the most important factors of production in farming (Asih, 2008). Sources of capital for farming can come from within (own capital) and from outside (loans / credit). The majority of farmers in the District of Panyingkiran in the category of the number of trees $\leq 50$ to $>200$ trees obtain a source of capital for independent mango farming. Among these capital is used for procurement of saprotan by buying their own according to the needs of their land from agricultural shops in the District of Panyingkiran. However, if it is associated with controlling the number of mango trees, the source of capital does not have a significant link at the population level.
Table 6. Chi-Square Test Results between Farmer Agribusiness Behavior and Ownership of Number of Mango Trees

\begin{tabular}{|c|c|c|c|}
\hline \multirow[t]{2}{*}{ No. } & \multirow{2}{*}{$\begin{array}{c}\text { Mango Farmer Agribusiness } \\
\text { Behavior }\end{array}$} & \multicolumn{2}{|c|}{$\begin{array}{l}\text { Ownership of Total } \\
\text { Mango Trees }\end{array}$} \\
\hline & & $\bar{r}$ & $p$ \\
\hline 1. & Source of capital & 715,917 & 0,134 \\
\hline 2. & Access to farm credit & 504,467 & $0,000 * *$ \\
\hline 3. & Use of family labor & 178,802 & 0,511 \\
\hline 4. & Application of off season technology & 326,040 & $0,011 *$ \\
\hline 5. & Pest (OPT) Control & 158,477 & 0,874 \\
\hline 6. & $\begin{array}{l}\text { Percent of good quality crops } \\
\text { (grade A / B) }\end{array}$ & 734,265 & $0,000 * *$ \\
\hline 7. & Market Selection & 112,610 & 0,920 \\
\hline 8. & Determining the selling price & 265,165 & $0,000 * *$ \\
\hline 9. & Payment system & 1358,516 & $0,000 * *$ \\
\hline 10 & Membership in farmer groups & 466,251 & $0,000^{* *}$ \\
\hline 11 & $\begin{array}{l}\text { Government contributions } \\
\text { related to mango farming }\end{array}$ & 469,615 & 0,252 \\
\hline
\end{tabular}

(Source: Primary Data, Processed, 2019)

Description:- ** Significant at the real level 1\%

- *Significant at the real level 5\%

- ris the Pearson Chi-Square value and $p$ is the opportunity value or real level (Asymp. Sig. 2 tailed).

Variable access to farm credit has a significant relationship with mastery of the number of mango trees in farmers in District of Panyingkiran, Majalengka Regency. Thus it can be interpreted that the greater ownership of the number of mango trees is also related to the better access of farmers to credit.Diagne (1999) state that access to credit is the ability of farmers individually or in groups to obtain capital facilities and financial services from banks / financial institutions or other sources of credit. The majority of farmers with ownership of the number of largescale farming trees ( $>200$ mango trees) many have access to credit in credit institutions such as banks and KUR (People's Business Credit) for farming capital. Meanwhile, farmers with small mastery of mango trees, it is difficult to access agricultural credit. Referring to Sulistyowati et al. (2015), the difficulty of small mango farmers in accessing credit is one of the factors that significantly influences to technical inefficiencies in mango farming.

Labor is an important factor of production and needs to be taken into account in the production process not only in terms of the availability of labor but also the quality and type of labor need to be considered (Soekartawi, 1994). Every production process requires adequate labor. The number of workers needs to be adjusted to the needs of a certain level so that the numbers are optimal.Based on the results of the study, the majority of farmers in the ownership category of the number of trees that use a variety of family labor in the activity of mango farming as many as 1 person (counting himself). For farmers with little control of the number of mango trees, mango farming activities are sufficiently carried out by themselves, whereas for farmers with mango trees many use 3-4 laborers who are not family members only during certain activities (such as fertilizing and harvesting). 
The variable application of off-season technology has a significant relationship with the mastery of the number of mango trees in farmers in the District of Panyingkiran, Majalengka Regency. Increased ownership of the number of trees is closely related to the adoption of off-season technology by farmers. Off season technique is a technique that can be used to produce plants or other crops outside the season that should be. Based on the results of the analysis it is known that $88 \%$ of mango farmers in the District of Panyingkiran have implemented off season technology in their mango farming activities. The results of Kusumo et al. (2018) actually is inversely proportional, namely that in the last 15 years off season technology has been found but only a small proportion of farmers apply, due to the lack of socialization and supply of inputs that are still difficult to reach by farmers.

Although they have applied off-season technology, farmers are also often faced with a decrease in mango production. The decline in production is one of them caused by weather and plant-disturbing organisms (OPT). When the rainy season arrives, pests and diseases more often arise such as the growth of mold on the fruit which causes the fruit to rot quickly and the skin of the fruit is not smooth (Downey et al., 1998).Pest control is a management action to suppress pest attacks at the level or threshold which is not detrimental to the economy, which is carried out massively and simultaneously, both preventive and responsive efforts (Directorate General of Food Crops Agriculture, 2015). The majority of farmers with control of the number of category 1 trees - more than 200 mango trees use pesticides as an effort to control pests. The use of pesticides is considered more practical and the results are quickly seen compared to using natural predators or pest traps. However, this variable does not have a significant relationship with the ownership of the number of mango trees.

Farmers with the authority of a variety of trees have set their own harvest time so that within one year can harvest mangoes 2-3 times. Harvesting system that is done is not by slash, because farmers feel that this method more often makes farmers lose because the value of the results of production cannot be predicted. After harvesting, the farmer can see the results of the mango harvest. Each farmer has a different quantity and quality. Based on Table 6 , the majority of farmers have been able to produce good quality mangoes reaching $50-70 \%$ of the overall crop yield. Farmers with a number of trees $\leq 50$ are even more dominant than farmers with trees $>200$ in producing good quality mangoes which reach $71-90 \%$ of the total harvest. This Percent Variable of good quality crop yields has a significant relationship with the ownership of the number of mango trees, which means an increase in the quality of mango harvest in the District of Panyingkiran, Majalengka Regency is very closely related to the ownership of the number of mango trees in farmers.

Farmers with ownership of the number of mango trees in all categories are more likely to sell their mangoes to middlemen. According to farmers, selling mango harvests to traders / middlemen is very easy and fast and can save time and transportation costs. That is because there are many collectors / middlemen around the residence and / or farmers' mango land so farmers are not too looking for other buyers. In addition, sometimes there are people who directly take the mango harvest to farmers' gardens and there are also farmers who deliver to the collectors / middlemen's warehouses around their home environment (Medina et al., 2002).However, this variable does not have a significant relationship with the ownership of the number of mango trees.

Furthermore, the determinants of mango selling price, payment system and membership in farmer groups have a significant relationship with the ownership of the number of mango trees, which means that the increase in these variables is very closely related to controlling the number of mango trees in the District of Panyingkiran, Majalengka Regency.Farmers who are members of farmer groups or partnerships have a high bargaining power towards the selling price of mangoes. Farmer groups according to Anonymous in Mardikanto (1993) are defined as a collection of peasants or consisting of adult farmers (men / women) and farmers (young men/women) formally bound in a family area on the basis of harmony and shared needs as well as located in the environment of the influence and leadership of a farmer. Based on the results of the study, it is known that the majority of farmers in the ownership category of diverse tree numbers $(55 \%)$ are not incorporated into a farmer group. That is because there are no active farmer groups in the village where the mango farmers live. The farmers who are the most members of the farmer group are farmers with a category of ownership $>200$ mango trees. The farmer is aware that there are many benefits to be gained by joining a farmer group.

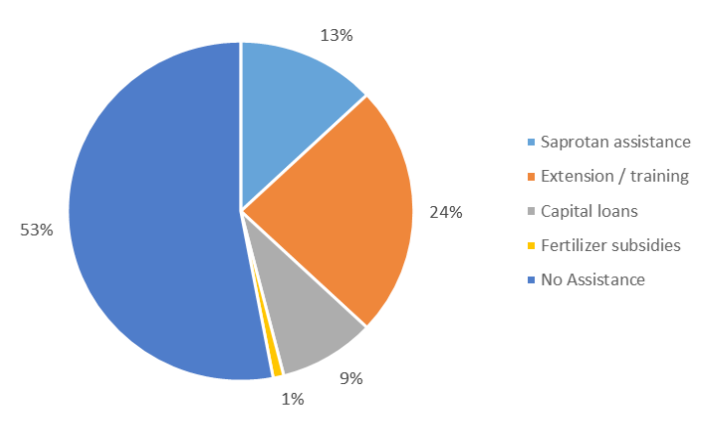

(Source: Primary Data, Processed, 2019)

Figure 3. Percentage of Mango Farmers Based on Government Assistances

Based on Table 6, it is known that Government contributions related to mango farming variable does not have a significant relationship with the ownership of the number of mango trees. It relates to Figure 3the majority of mango farmers namely $53 \%$ have never received government contributions in the form of materials such 
as saprotan assistance, extension / training, capital loans, fertilizer subsidies and others. Only $13 \%$ and $24 \%$ of the total respondent farmers stated that they had received saprotan assistance and extension / training activities from the government or the local Agriculture Service.

\section{Potential of Mango Farming}

1. Ease of getting farming capital

The ease of access to capital for mango farming turns out to be the potential of mango farming in the District of Panyingkiran, Majalengka Regency. From the results of research in the field it is known that the majority of respondents of mango farmers find it easy to get farming capital (Figure 4). This can be a good potential considering that many banks even offer capital loans to door to door. This is in line with the results of research Rasmikayati et al. (2018) concerning the potential of mango agribusiness in Indramayu Regency where one of its potential is ease of access to farming capital.

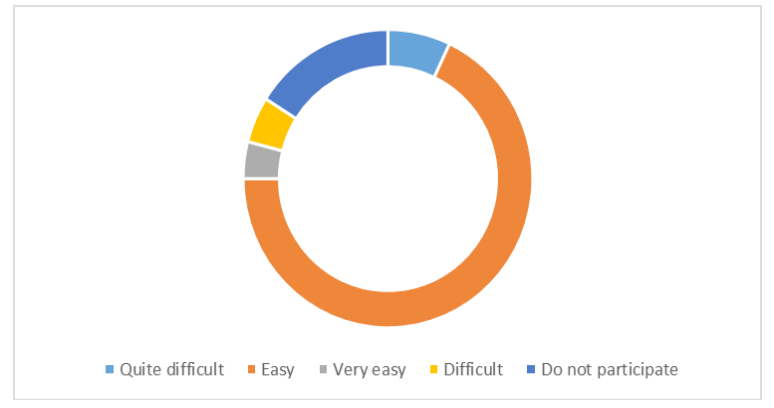

(Source: Primary Data, Processed, 2019)

Figure 4. Percentage of Mango Farmers Based on Ease of getting farming capital

2. Ease of cultivation techniques

Mango farmers find it easy to do mango cultivation techniques. This is because farmers are accustomed to doing it, besides that in general mango farming is inherited from parents so it is no stranger to cultivation techniques that must be done.

\section{Constraints on Mango Farming}

One of the biggest and most difficult obstacles in its handling at this time is uncertain weather. High rainfall and often make flowers on mango trees quickly fall out. This makes it difficult and burdensome for farmers to have to increase the dose and frequency of fertilization. In addition, high rainfall also makes pests and diseases easily come. As a result of this weather, even if the flowers on a mango tree survive until it turns into a fruit, the fruit produced tends not smooth and many black spots appear on the skin. This certainly makes the quality of mangoes become less good. The maintenance costs will certainly increase in bad weather conditions. Farmers often complain that the price of medicines is getting more and more expensive. Sometimes farmers also find that drugs sold in saprotan shops are fake drugs. This is still not supported by stable selling prices.

\section{CONCLUSION}

Farmers with tree status ownership $<50$ of mango trees on their land while farmers who control $>200$ mango trees are farmers with leased tree status,Farmers with small, medium, and large amounts of mango tree tenure use private capital to cultivate mangoes and easily gain access to farm credit. The farmer makes the middleman as the final market destination and uses a cash payment system in buying and selling transactions. The majority of farmers with little, medium, and many tree tenure are not incorporated into farmer groups and have never received government contributions related to mango farming in any form. There are 6 variables of agribusiness behavior of mango farmers in the District of Panyingkiran, Majalengka Regency, which have a close and significant relationship with mastery of the number of mango trees, namely access variables to farm credit, application of off season technology, percent of good quality yields (grade A / B), determinants of selling prices, payment systems and membership in farmer groups.

\section{ACKNOWLEDGMENTS}

Our gratitude goes to the Higher Education Basic Research (PDUPT) DIKTI program that has funded our research and publications.

\section{REFERENCES}

Asih, D.N. (2008). Credit Policy Analysis on Developing Traditional Fisheries in the Regency of Tojo UnaUna. J. Agroland, 15, (1): 36-44.

Diagne, A., (1999). Determinants of Household Access to and participation in Formal and Non formal Credit Markets in Malawi. Food Consumption and Nutrition Division (FCND) Discussion Paper 67, IFPRI, Washington.

Directorate General of Horticulture, Ministry of Agriculture. (2015). Horticultural Production Statistics 2014.

Direktorat Jendral Hortikultura Kementrian Pertanian. Accessed through http:/hortikultura.pertanian. go.id (on January 29, 2019)

Downey, W.D., and S.P Erickson. (1998). Agribusiness Management. 2nd edition, print. The 3rd. Jakarta: Erlangga. Translation from: Agribusiness Management.

Elfadina, E.A., Rasmikayati, E. \& Saefudin, B.R. (2019). Analisis Luas dan Status penguasaan Lahan Petani Mangga Dikaitkan dengan PerilakuAgribisnisnya Di Kecamatan Cikedung Kabupaten Indramayu. Jurnal Ilmiah Mahasiswa Agro info Galuh, 6, (1), 69-79. DOI: http://dx.doi.org/10.25157/jimag.v6i1.1376. 
Hapsari, H., Rasmikayati, E. \& Saefudin, B. R. (2019). Karakteristik Petani dan Profil Usaha tani Ubi Jalar Di Kecamatan Arjasari, Kabupaten Bandung. Sosiohumaniora, 21, (3), 247-255. DOI: https:// doi.org/10.24198/sosiohumaniora.v21i3.21288.

Irianto, H. \& Widiyanti, E. (2013). Value Chain Analysis and Marketing Efficiency of Ear Mushroom Agribusiness in the Regency of Karanganyar. Journal of Agriculture Socio-Economic and Agribusiness. 9, (2): 260-263.

Kast, F.E. \& Rosenzweig, J.E. (1995). Organization and Management. Volume 1, Edition. $4^{\text {th }}$, Print. $4^{\text {th }}$ Jakarta: Penerbit Bumi Aksara.

Kusumo, R.A.B., Rasmikayati, E., Mukti, G.W., Fatimah, S. \& Saefudin, B.R. (2018). Faktor-Faktor yang Mempengaruhi Keputusan Petani Mangga dalam Menggunakan Teknologi Off Season Di Kabupaten Cirebon. Mimbar Agribisnis: Jurnal Masyarakat Ilmiah Berwawasan Agribisnis, 4, (1), 57-69. Accessed through https://jurnal. unigal.ac.id/index.php/mimbaragribisnis/article/ view/789.

Mardikanto, T. (1996). Forestry Development Counseling. Jakarta:Department of Forestry

Medina, J. De La Cruz. \& Garcia, H. S. (2002).Mango: Post-harvest Operation. Food and Agriculture Organization of United Nation (FAO). Veracruz.

Rachmah, A.D., Rasmikayati, E. \& Saefudin, B.R. (2019). Factors Related to Continuation of Mango Cultivation. JurnalPertanian, 10, (2), 52-60. DOI: http://dx.doi.org/10.30997/jp.v10i2.1864.

Rasmikayati, E. (2018). Kajian Potensi dan Kendala dalam Proses Usahatani dan Pemasaran Mangga Di Kabupaten Indramayu. Sosiohumaniora, 20, (3), 215-221. DOI: https://doi.org/10.24198/ sosiohumaniora.v20i3.15859.
Rasmikayati, E., Mukti, G.W., \& Saefudin, B.R. (2019, October). The Determinant Factors of The Dynamics of Agribusiness Behavior of the Mango Farmers in Greged Sub District, Cirebon District. In IOP Conference Series: Earth and Environmental Science, 334, (1), p. 012054). IOP Publishing. DOI: https://dx.doi.org/10.1088/17551315/334/1/012054.

Rasmikayati, E., Sulistyowati, L. \& Saefudin, B. R. (2017). Resiko Pemasaran terhadap Pendapatan Petani Mangga: Kelompok Mana yang Paling Berisiko. Mimbar Agribisnis: jurnal Pemkiran Masyarakat Ilmiah Berwawasan Agribisnis, 3, (2), 105-116. DOI: http://dx.doi.org/10.25157/ma.v3i2.564.

Sari, A.F., Rasmikayati, E., \& Saefudin, B.R. (2019). Behavioral Dynamics of Farmers and First Buyer in Marketing Mangoes in Sedong District, Cirebon Regency, West Java. AGRIFOR, 18, (1), 63-72. Accessed through http://ejurnal.untag-smd.ac.id/ index.php/AG/article/view/4072.

Soekartawi. (1994). Agribusiness: Theories and Applications. Jakarta: PT. Raja Grafindo Persada.

Sulistyowati, L., Natawidjaja, R.S., \& Rahmat, B. (2015). Adoption of Technology and Economics Efficiency of The Small-holder Mango Farmers in Indonesia. International Journal of Applied Business and Economic Research (Ijaber), 13, (7), 4621-4645. ISSN: 0972-7302. Serial Publication PVT. LTD. New Delhi. India.

Suparta, Nyoman. (2005). Agribusiness Behavior and Extension Needs of Broiler Farmers. [Dissertation]. Bogor Agricultural Institute. Bogor. 